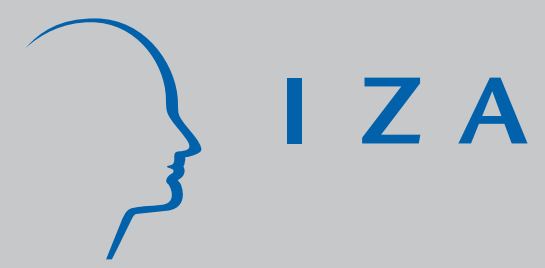

IZA DP No. 8909

Worker Morale and Effort: Is the Relationship Causal?

Wolter H.J. Hassink

Roberto M. Fernandez

March 2015

Forschungsinstitut zur Zukunft der Arbeit Institute for the Study of Labor 


\title{
Worker Morale and Effort: Is the Relationship Causal?
}

\author{
Wolter H.J. Hassink \\ Utrecht University \\ and IZA
}

Roberto M. Fernandez

MIT Sloan School of Management

\section{Discussion Paper No. 8909 \\ March 2015}

\author{
IZA \\ P.O. Box 7240 \\ 53072 Bonn \\ Germany \\ Phone: +49-228-3894-0 \\ Fax: +49-228-3894-180 \\ E-mail: iza@iza.org
}

\begin{abstract}
Any opinions expressed here are those of the author(s) and not those of IZA. Research published in this series may include views on policy, but the institute itself takes no institutional policy positions. The IZA research network is committed to the IZA Guiding Principles of Research Integrity.

The Institute for the Study of Labor (IZA) in Bonn is a local and virtual international research center and a place of communication between science, politics and business. IZA is an independent nonprofit organization supported by Deutsche Post Foundation. The center is associated with the University of Bonn and offers a stimulating research environment through its international network, workshops and conferences, data service, project support, research visits and doctoral program. IZA engages in (i) original and internationally competitive research in all fields of labor economics, (ii) development of policy concepts, and (iii) dissemination of research results and concepts to the interested public.
\end{abstract}

IZA Discussion Papers often represent preliminary work and are circulated to encourage discussion. Citation of such a paper should account for its provisional character. A revised version may be available directly from the author. 


\section{ABSTRACT}

\section{Worker Morale and Effort: Is the Relationship Causal?*}

We investigate a unique setting which enables us to distinguish between two theories of work performance. A standard labor supply framework implies a negative effect of the nonpecuniary cost of work on the employee's effort. In contrast, a model of worker morale that is consistent with a widely used theory of Akerlof and Yellen (QJE,1990) predicts this negative effect is stronger (weaker) for low-morale (high-morale) workers. We exploit a natural experiment design of a firm relocation from Milwaukee's Central Business District to the area's suburban ring in 1992. Since the employees did not choose the location of the new plant, there is an exogenous source of variation on the adjusted commuting distance among those who stay at the firm. Some of the workers received a windfall gain, whereas other workers experienced an unforeseen cost in longer commuting time. The estimates indicate that low-morale workers are responsive to the shock in commuting time. We conclude that the results favor the model of worker morale.

JEL Classification: J24, J31, M52

Keywords: $\quad$ worker morale, absenteeism, natural experiment

Corresponding author:

Wolter H.J. Hassink

Utrecht School of Economics

Kriekenpitplein 21-22

3584 EC Utrecht

The Netherlands

E-mail:w.h.j.hassink@uu.nl

\footnotetext{
${ }^{*}$ We are grateful to seminar participants at University of Bergen, SOLE Meetings (Chicago), Frisch Centre/NOVA (Oslo), EALE (Bonn), Belgian Day for Labor Economists (Leuven), and a Workshop on Absenteeism and Social Insurance (Bergen). We appreciate comments by Maarten Goos, Dan Hamermesh, Per Johansson, Ed Lazear, Gerard Pfann, Knut Røed, Giovanni Russo, and Kjell Vaage.
} 


\section{Introduction}

The management literature has provided abundant evidence that firms spend resources to increase the commitment and loyalty of their work force, and that these investments are likely to pay off (Pfeffer, 1994, 1998; O’Reilly and Pfeffer, 2000). In other words, by putting their people first, profits to the firms will be increased. But does worker loyalty produce better job performance?

On the one hand, many economists would be skeptical of claims of worker morale mattering because of the issue of adverse selection. Simply put, workers with a poor bargaining position in the external labor market - those with bad external prospects - would declare themselves to be loyal to the firm and display high morale. Consider a firm where there is an adverse change in the cost of paid work, making work at this firm less attractive (more costly) to the worker. The reaction to this shock would differ across workers depending on the attractiveness of the outside option. High-morale workers with a worse outside option would be less inclined to leave the firm than those with good external options, because they are less likely to find another employer where they can receive equivalent earnings. Therefore, by setting a higher wage, the firm can worsen the relative attractiveness of the worker's external options, so that the firm can in effect purchase worker morale. If raising wages is always available as an option to induce the appropriate behavior, why would a firm need to pay any attention at all to worker morale?

On the other hand, other research in economics is more sympathetic with the idea that many researchers have considered a class of models of worker's morale and their commitment to the firm (Bewley, 1999). It is based on the starting point that worker's utility may be based on non-pecuniary variables in addition to monetary variables and costly effort. Commitment to the firm may be shaped by the firm's identity (Akerlof and Kranton, 2005). According to this line of reasoning, to the extent that there are non-monetary attributes of the job that are part of the worker's utility function, improving worker morale can be employed as an a means of inducing effort from workers, leading to higher productivity (Akerlof and Kranton, 2005). Additionally, worker morale may be important to a firm as a means of establishing a long-run relationship between the worker and the firm, over and above the firm's reputation and the content of the labor contract (Bolton, 1990). From the firm's perspective, such a long-term orientation can be very useful as a means of withstanding unanticipated adverse market shocks. 
Distinguishing between these two lines of thought on the role of worker morale is empirically very difficult. To gauge the effect of morale on the worker's productivity, we are confronted by an econometric identification issue. First, both aforementioned explanations imply that an increase in the costs of paid work to the worker (changes that make it is costlier to have a match with the employer) lead to lower production. Thus, in order to discriminate between these theories, in addition to data on productivity, information on worker morale and her outside option is also needed. This raises a second thorny issue, i.e., how does one measure morale independent of changes in worker's behavior in the face of increased costs to the paid worker? Third, even if these challenges could be overcome, were we to observe relationships among worker morale, output, effort, and the value of the outside option, we could not be sure of the causal order of these effects. It is hard to find an exogenous source of variation to the worker in long-run relationships, which can be related to differences in worker morale and the outside option. ${ }^{1}$

In this study, we apply a design that is driven by an exogenous shock in the non-pecuniary cost of work. It is based on the prediction that increased commuting time leads to lower productivity (through higher absence) and a higher likelihood of separation from the employer. We consider a firm in downtown Milwaukee that moved from the central city to a suburb of that town, which is located about 10.5 miles away from the old plant. From the worker's perspective, this plant relocation comes as an exogenous shock in commuting time. ${ }^{2}$ For some workers who need to commute over longer distances it is experienced as an unforeseen additional cost, while for the other workers it constitutes a windfall gain in time. Exploiting this exogenous information, we observe that the negative shock of a longer commuting distance elicits lower worker productivity measured in the form of higher absenteeism.

According to worker morale theories, the response to the shock should differ across employees. High-morale workers should not respond to a negative shock, either in terms of productivity and/or separation from the firm, whereas low-morale workers should respond to the longer commute by lowered productivity and/or seeking external options for employment.

\footnotetext{
${ }^{1}$ The scope condition of the laboratory experiments is short-run relationships. See for instance Fehr and Falk (1999) and Fehr and Gächter (2002).

${ }^{2}$ This setup of such a shock variable that results from a change of a location of a firm from the city center to the suburbs has been applied in studies designed to test the spatial mismatch hypothesis regarding race differences in labor market behavior (Fernandez 1994, 2008; Zax 1989, 1990; Zax and Kain 1991, 1996; for a review, see Fernandez and Su (2004), pp. 547-53).
} 
Exploiting a combination of this shock with ex ante information on the worker's morale prior to the shock, our estimates indicate that over all workers, there is a negative effect of the adverse circumstance on work effort. However, this effect is absent for the workers who stated prior to the move that they had relatively high morale. In contrast, for the workers who declared themselves to have low-work morale at time 1, the shock has a strong negative impact on work effort. Moreover, supporting the idea that the morale effect is causal, the effect of the shock does not change with differences in the worker's assessments of the strength of their outside options prior to the shock.

The paper has the following structure. In Section 2 gives the conceptual framework of morale. In Section 3 the plant's relocation, the shock variable of commuting time and the measures of worker morale are described in great detail. Section 4 considers the statistical identification strategy. In Section 5 the estimates are presented. The robustness checks are given in Section 6. The conclusion is given in Section 7.

\section{Conceptual framework}

Worker morale is a broad concept. Various classes of theories of employee performance are based on the key issue of worker morale and loyalty. It includes theories of the identity of organizations (Akerlof and Kranton, 2005), exit, voice, and loyalty (Hirschmann, 1970), reciprocity and gift exchange (Akerlof , 1982), and team spirit (Kandel and Lazear, 1992). Bewley (1998, p. 476) applies the following definition: "Morale is the acceptance and willingness to contribute to organizational objectives and is important because people tend to benefit those who help them and to hurt those who harm them. (...) good morale implies willingness to make personal sacrifices for the good of the organization."3 According to interviews of Campbell and Kamlani (1997) and Bewley (1998) managers emphasize that morale is an important reason why employers do not want to decrease their nominal wage, because they expect workers to respond to such decreases with lower effort.

We consider worker morale against the backdrop of the influence of the cost of work on work performance. Broadly speaking, two opposite approaches have been developed in different literatures. The first approach - that excludes morale - is based on the assumption

\footnotetext{
${ }^{3}$ As such, this definition is related to the concept of "organizational citizenship behavior" and "organizational commitment" in the organizational psychology literature (Mowday, Porter and Steers 1982; Podsakoff et al. 2009).
} 
that effort is reduced by a higher disutility (or cost) of work to the worker. The marginal change of effort at the intensive margin is 4

$$
\frac{\partial E}{\partial c}<0
$$

where $E$ is effort, and $c$ is cost of work to the worker. Many empirical studies of worker effort are based on this simple framework. The cost variable $c$ includes family conditions or home production (Vistnes, 1997), commuting distance to work (Allen, 1981), work incentives (Barmby et al. 1991; Johansson and Palme, 1996; Ichino and Riphahn, 2005; Hassink and Koning, 2009), as well as the bargaining position of the worker on the external labor market (Arai and Thoursie, 2005). There is no need to include morale in this framework, since morale is posited to be inversely related to the worker's bargaining position.

The second approach is based on the influence of worker morale on effort. More specifically, it leads to the mechanism that firms may benefit from a work force with high morale, because it may help cushion the effect of an adverse shock on the cost of effort for high-morale workers. This mechanism can be shown in a reformulation of the framework developed by Akerlof and Yellen (1990) to explain unemployment. In such a framework, workers can be distinguished with respect to morale. High-morale workers provide the usual effort $E$ - indicated by $m$ and normalized at one - whereas those with low morale provide effort below the usual level: ${ }^{5}$

$$
E=\min (m, 1) \quad m>0
$$

Thus, for low-morale workers a change of effort can be accomplished if their worker morale is changed. For instance, a wage gift would induce reciprocal behavior of the worker toward the firm in the form of higher work effort.

The intuition behind the second approach is that equation (1) does not allow for any interaction between a change in the cost of work and initial morale. However, the response to an increase of the cost of work may be stronger for a low-morale worker than for a high-

\footnotetext{
${ }^{4}$ Of course, it is a very stylized expression, which can be made richer by including worker's benefit and the firm's costs and benefits of maintaining the high effort of the worker. We abstract from effort at the extensive margin (separations).

${ }^{5}$ Akerlof and Yellen related worker morale to a fair wage $m=w / w^{*}$, for which $w$ is defined as the market clearing wage and $w^{*}$ is the worker's fair wage.
} 
morale worker. It may be formalized by adding a cost of effort $c$ to both groups of workers. ${ }^{6}$ Effort is decreasing in $c$ for all workers:

$$
E=\min \left(e^{-c / m}+m, e^{-c}+1\right) \quad c, m>0
$$

For high-morale workers $\left(m \geq 1+e^{-c}-e^{-c / m}\right)$ the marginal change of effort is

$$
\frac{\partial E}{\partial c}=-e^{-c}
$$

whereas for low-morale workers, the marginal change of effort depends on their worker morale.

$$
\frac{\partial E}{\partial c}=-\frac{1}{m} e^{-c / m}
$$

The important implication of equation (2) is that the change of effort is stronger for workers with low morale:

$$
\left|\frac{\partial E}{\partial c}\right|_{m \text { large }}<\left|\frac{\partial E}{\partial c}\right|_{m \text { small }}
$$

So far, the empirical literature on morale and workplace performance has concentrated on the reciprocal mechanism of equation (2), in which a change in morale induces a change of effort. Lee and Rupp (2007) considered the effect of wage cuts on performance of airline pilots. They found a strong negative decline of effort, which is however short lived and is limited to non-bankrupt airlines. Cohn, Fehr, Hermann, and Schneider (2011) found evidence of a fair wage, which is determined by reference and social comparison with their team members' wages. The estimates of Kube, Maréchal, and Puppe (2012) were based on a field experiment in the workplace, which resulted in evidence of reciprocity.

In all of the aforementioned studies, changes in morale of individual workers were evoked by imposing different rewards relative to some measure of a fair wage. To get a measure of differences in the level of morale across workers, there are stronger requirements on the quality of the data. The organizational literature has developed various measures of dimensions of employee morale (Podsakoff et al., 2000, 2009). As far as we know, these measures have not been used in an empirical analysis of worker performance based on quasiexperimental design.

\footnotetext{
${ }^{6}$ Effort is normalized at one for workers with zero $c$.
} 


\section{The firm}

We study a food processing firm that publicly announced in the fall of 1989 that it was going to relocate the plant from Milwaukee's Central Business District to the area's suburban ring in 1993. The firm invested $\$ 92$ million in building a new facility located about 10.5 miles from the old plant. The old facility was located in a 100 year old, cramped, multi-story plant. The new facility allowed for a massive upgrade of the production equipment. The new machines delivered higher quality, and there was a clear increase in the productivity of the new plant. In making the decision, the firm's management considered three alternative suburban locations. They conducted a study measuring what the commuting distance would be for each of the incumbent workers to the three alternative sites, and then chose the location that was the least disruptive to workers' commutes. For detailed descriptions of the case, see Fernandez (1994, 2001, 2008).

Fernandez (1994) argued there was good evidence that the firm was not relocating to change the work force. First, the firm announced that there was no intention to dismiss the current employees through the move, and publicly gave the incumbent workforce a no-layoff guarantee. In addition, the firm's management publicly guaranteed workers an hourly wage in the new plant which was to be no less than their wage in the old plant.

The firm's workforce was studied before and after the firm relocation. The survey data were collected by face-to-face interviews with all employees in spring 1991, which was about six to nine months before the relocation of the firm. In 1994 the workforce was surveyed again, also tracking those workers who left the firm (Fernandez, 2008). Respondents received $\$ 15.00$ (\$50.00) for participating in the first (second) wave of the survey. Of the 337 employees who were employed in the production plant in 1991, a total of 252 employees stayed with the firm through the transition to the new plant. Of these, 178 employees responded to surveys for both periods (78 white-collar, and 100 blue-collar employees). In addition, there is survey information for available for 71 employees who left the firm (34 white-collar, and 37 blue-collar workers).

For all employees in 1991, information of their postal address was available, so that it was possible to measure the road map commuting time from their 1991 address to both the downtown plant and suburban locations. Our empirical analysis will be based on the time to commute to both locations. It is defined as

$\operatorname{com}_{91}=$ total round-trip commuting time (in hours) from 1991 residence to old location 
$\operatorname{com}_{94}=$ total round-trip commuting time (in hours) from 1991 residence to new location

The size of the shock is the difference between $\operatorname{com}_{94}$ and com $_{91}$. From the perspective of the worker, there is no additional utility attached to commuting. Of course, the response to the shock could be different across groups of workers. However, the firm did not compensate any (additional) costs of commuting. Neither was there any change of the incentive structure to the employees. All workers came by car in 1994.

Since the employees did not choose the location of the new plant and the relocation decision of the firm was not focused on specific groups of workers either, there is an exogenous source of variation on the commuting distance among the workers. For those who stayed with the firm, 27 workers (15 percent) got a windfall decrease in commuting time, whereas the remaining 151 workers got an increase in commuting time. ${ }^{7}$

Figure 1A - Difference between $\operatorname{com}_{94}$ and $\operatorname{com}_{91}$ (white-collar workers and blue-collar workers) - Stayers

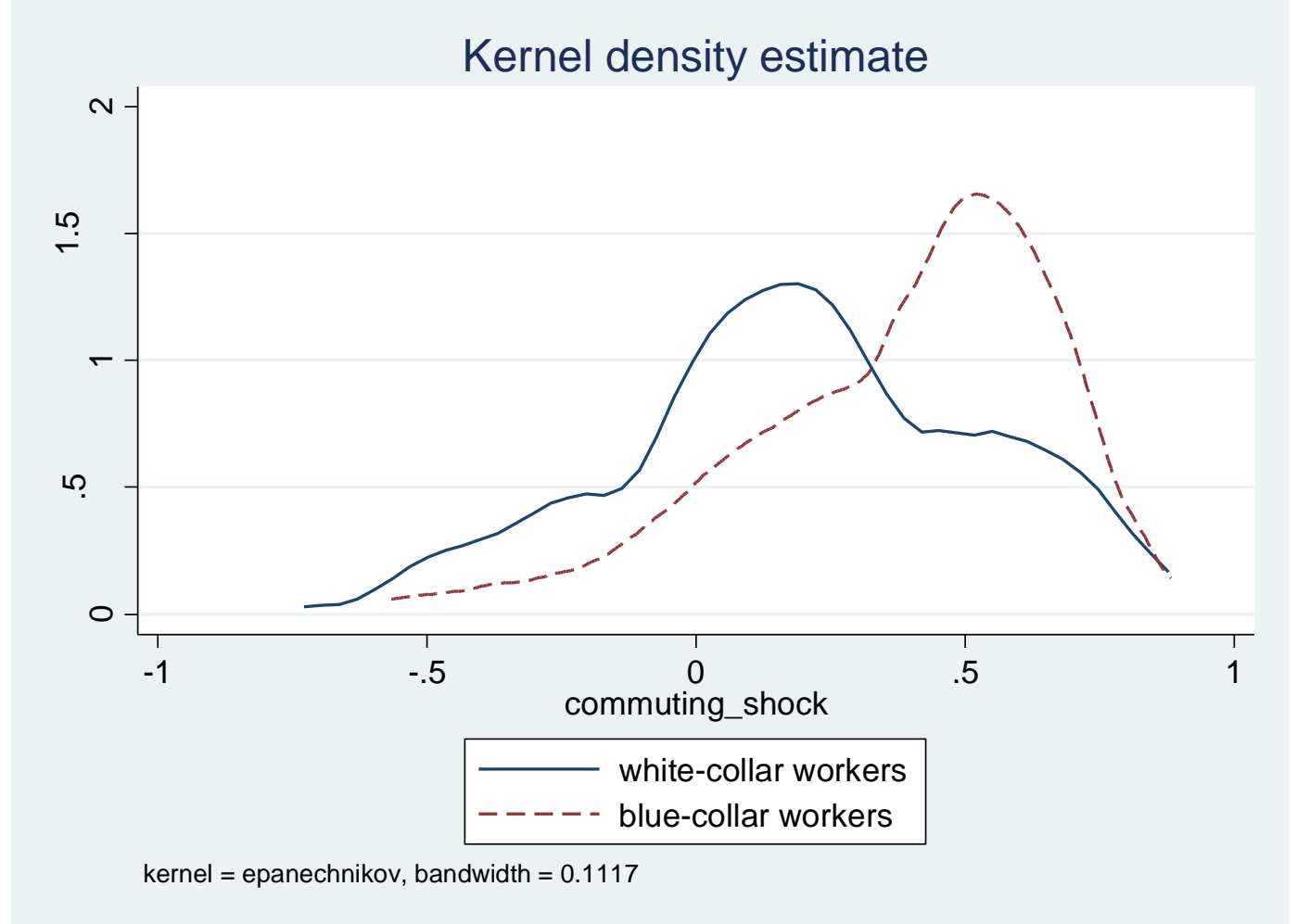

\footnotetext{
${ }^{7}$ For the leavers, 13 workers (18 percent) got a reduction in commute, and 58 workers had an increase in commuting time.
} 
Figure 1B - Difference between $\operatorname{com}_{94}$ and $\operatorname{com}_{91}$ (white-collar workers and blue-collar workers) - Leavers

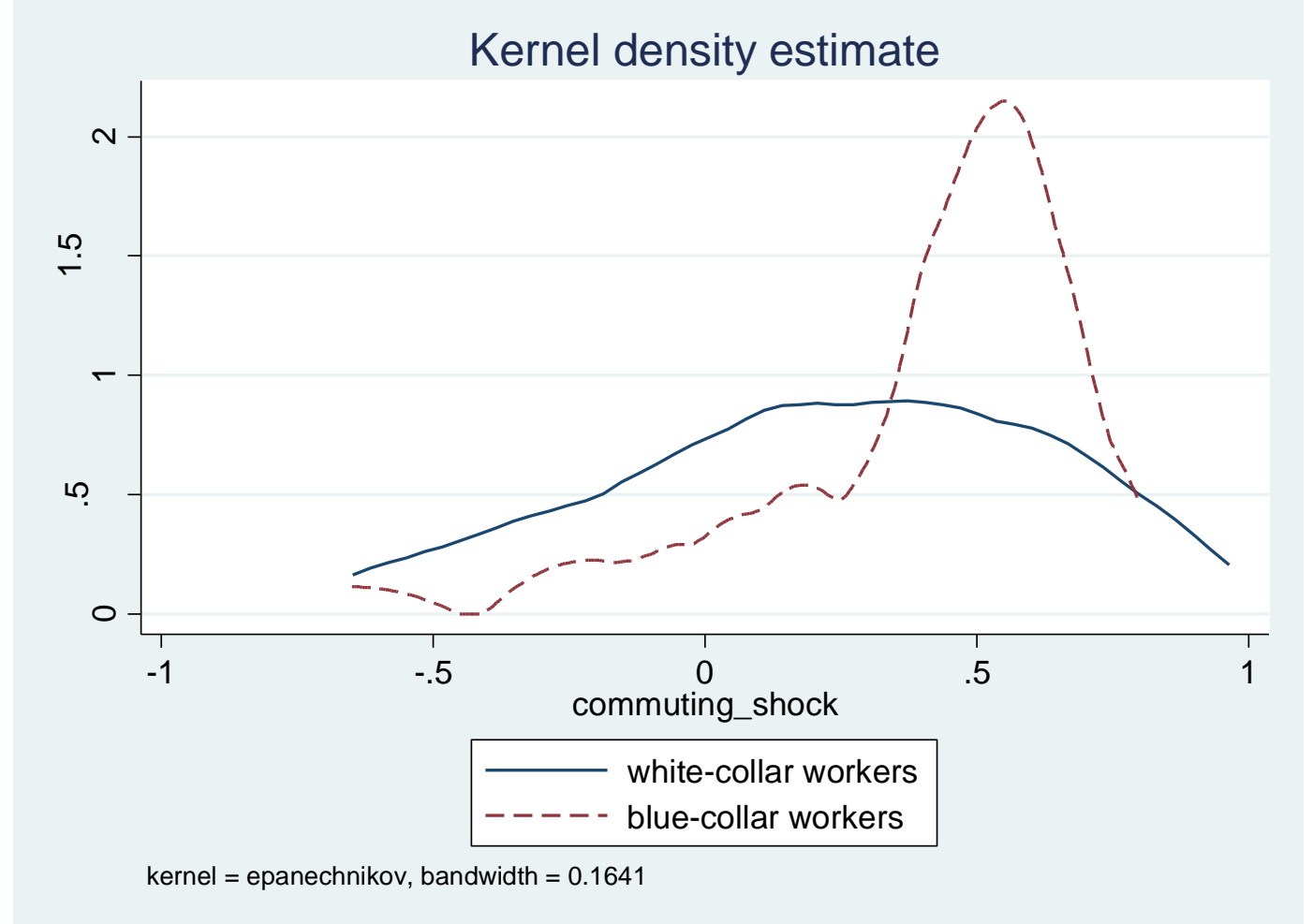

Figure 1A shows for the stayers that the increase in commute was more substantial for the blue-collar workers than for the white-collar workers. This finding is corroborated for the leavers in Figure 1B.

The firm had a capital-intensive production process in both locations. Unionized bluecollar workers were operating the machines in various production lines. Absenteeism of these workers was costly to the firm, because replacement workers had to be hired and it could also affect the productivity of the other blue-collar workers because of the interdependencies or complementarity in production. According to the union contract, the blue-collar workers were allowed to be absent from work for funeral leave, personal leave, illness or injury, armed forces, maternity leave, and family and medical leave. For the remaining white-collar workers the consequences of absence did not have an immediate impact on the production process, but they felt the pressure of caught shirking through an employment-at-will contract. Hence, for the white-collar workers, the rules about absence were more flexible and depend on the 
supervisor. ${ }^{8}$ For both groups of workers, the firm could not perfectly monitor the validity of absence, so that there was some scope to shirk through workplace absence.

We take absenteeism as a measure of effort, for which we follow a broad literature (Johansson and Palme, 1996; Røed and Fevang, 2007; Ichino and Moretti, 2009; Treble and Barmby, 2011; Ziebarth and Karlsson, 2014). Hours of work is a less suitable measure of effort for this particular firm, because there is hardly any variation in the contractual hours and overtime of work. White-collar workers are expected to work a minimum of 40 hours. They are exempt from overtime regulation, so they can work more on some days and then less on other days.

Absenteeism was asked to the workers in both waves of the survey as: "About how many days would you say that you are absent from work during the average month not counting vacations and paid holidays?" Table 1 shows the averages of the key variables before and after the plant relocation, across the categorizations blue-collar/white-collar workers and stayers/leavers. The decline in absence was stronger for the blue-collar workers (from 0.47 to 0.28 days a month) than for white-collar workers (from 0.14 to 0.12 days a month). In terms of the indicator of monthly absence (one if absent on one of the working days of the month), the declines were from 49 to 20 percent (blue-collar workers), and from 23 to 12 percent (white-collar workers), respectively. The average commuting time increased from 0.45 hours (from 1991 residence to old factory) to 0.82 hour (from 1991 residence to new factory) for the blue-collar workers and from 0.74 to 0.94 hour for the white-collar workers. Especially noteworthy for our purposes is the survey question on the worker's outside option. ${ }^{9}$ The difficulty of finding a comparable job (on a 10-point Likert scale where 10 is "Very Easy") is on average 3.71 for the blue-collar workers, and 4.77 for the whitecollar workers so that they reported they have a better outside option. These outcomes hardly changed between 1991 and 1994.

\footnotetext{
${ }^{8}$ Note that well after the period of our study, Milwaukee passed paid sick days standards that included paid "safe" days for victims of domestic violence, sexual assault and stalking (National Partnership for Women \& Families, 2013).

${ }^{9}$ The question was formulated as follows. "On a scale of 1 to 10 where 1 is very easy and 10 is very hard, how easy would it be for you to find another employer located nearby with approximately the same income and fringe benefits as your job at (this firm)?" We reverse coded this question, so that 10 corresponds to a very easy job change. Our reverse coding, which of course does not change the statistical results, leads to an easier interpretation of the coefficient on the outside option.
} 
Table 1 - Descriptive statistics for blue-collar and white-collar workers

\begin{tabular}{|c|c|c|c|c|c|c|}
\hline & \multicolumn{3}{|c|}{ Stayers } & \multicolumn{3}{|c|}{ Leavers } \\
\hline & mean & std & median & mean & std & median \\
\hline \multicolumn{7}{|l|}{ Blue-collar workers } \\
\hline Absenteeism (in days per month), 1991 & 0.47 & 0.67 & 0 & 0.53 & 0.85 & 0 \\
\hline Absenteeism (in days per month), 1994 & 0.28 & 0.68 & 0 & - & & \\
\hline Monthly incidence of absenteeism $(=1), 1991$ & 0.49 & 0.50 & 0 & 0.47 & 0.51 & 0 \\
\hline Monthly incidence of absenteeism (=1), 1994 & 0.20 & 0.40 & 0 & - & & \\
\hline $\begin{array}{l}\text { Road map commuting time to old factory in hours, } \\
\text { from } 1991 \text { residential location }\end{array}$ & 0.45 & 0.43 & 0.34 & 0.35 & 0.35 & 0.23 \\
\hline $\begin{array}{l}\text { Road map commuting time to new factory in hours, } \\
\text { from } 1991 \text { residential location }\end{array}$ & 0.82 & 0.37 & 0.77 & 0.75 & 0.28 & 0.75 \\
\hline Age (in years) & 37.8 & 9.0 & 36.0 & 39.4 & 12.8 & 34.0 \\
\hline Tenure (in years) & 9.6 & 6.8 & 8.9 & 7.7 & 8.3 & 4.0 \\
\hline Hourly wage in \$, 1991 & 10.17 & 1.85 & 9.87 & 9.79 & 1.94 & 9.51 \\
\hline Female $(=1)$ & 0.35 & 0.48 & 0 & 0.32 & 0.47 & 0 \\
\hline House move between 1991 and $1994(=1)$ & 0.43 & 0.50 & 0 & 0.65 & 0.49 & 1 \\
\hline $\begin{array}{l}\text { Difficulty of finding another job (10 is very easy; } 1 \\
\text { is very hard), } 1991\end{array}$ & 3.71 & 2.50 & 3 & 3.85 & 2.78 & 3 \\
\hline $\begin{array}{l}\text { Difficulty of finding another job (10 is very easy; } 1 \\
\text { is very hard), } 1994\end{array}$ & 3.84 & 2.50 & 3 & - & & \\
\hline Number of observations & \multicolumn{3}{|c|}{100} & \multicolumn{3}{|c|}{34} \\
\hline \multicolumn{7}{|l|}{ White-collar workers } \\
\hline Absenteeism (in days per month), 1991 & 0.14 & 0.34 & 0 & 0.20 & 0.33 & 0 \\
\hline Absenteeism (in days per month), 1994 & 0.12 & 0.32 & 0 & - & & \\
\hline Montly incidence of absenteeism (=1), 1991 & 0.23 & 0.42 & 0 & 0.32 & 0.47 & 0 \\
\hline Monthly incidence of absenteeism (=1), 1994 & 0.12 & 0.32 & 0 & - & & \\
\hline $\begin{array}{l}\text { Commuting time to old factory in hours, from } 1991 \\
\text { residential location }\end{array}$ & 0.74 & 0.51 & 0.66 & 0.73 & 0.75 & 0.52 \\
\hline $\begin{array}{l}\text { Commuting time to new factory, from } 1991 \\
\text { residential location }\end{array}$ & 0.94 & 0.46 & 0.88 & 0.97 & 0.57 & 0.85 \\
\hline Age (in years) & 39.7 & 9.6 & 39.0 & 37.9 & 12.4 & 35.0 \\
\hline Tenure (in years) & 7.5 & 6.9 & 5.8 & 8.5 & 10.6 & 3.8 \\
\hline Hourly wage in \$, 1991 & 15.24 & 5.65 & 14.38 & 15.81 & 8.13 & 13.02 \\
\hline Female $(=1)$ & 0.37 & 0.49 & 0 & 0.51 & 0.51 & 1 \\
\hline House move between 1991 and $1994(=1)$ & 0.27 & 0.45 & 0 & 0.46 & 0.51 & 0 \\
\hline $\begin{array}{l}\text { Difficulty of finding another job (10 is very easy; } 1 \\
\text { is very hard), } 1991\end{array}$ & 4.77 & 2.21 & 5 & 5.81 & 2.50 & 5 \\
\hline $\begin{array}{l}\text { Difficulty of finding another job (10 is very easy; } 1 \\
\text { is very hard), } 1994\end{array}$ & 4.36 & 2.30 & 4 & - & & \\
\hline Number of observations & \multicolumn{3}{|c|}{78} & \multicolumn{3}{|c|}{37} \\
\hline
\end{tabular}


Table 2 - Questions about worker morale, stayers (178 workers)

\begin{tabular}{|c|c|c|c|c|c|c|c|}
\hline Worker morale question M1 - M8 ${ }^{\text {a) }}$ & $\begin{array}{c}\text { Median } \\
1991\end{array}$ & 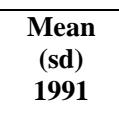 & $\begin{array}{c}\text { Median } \\
1994\end{array}$ & $\begin{array}{c}\begin{array}{c}\text { Mean } \\
\text { (sd) } \\
1994\end{array} \\
\end{array}$ & $\begin{array}{c}\text { I }(>\text { median }) \\
1991\end{array}$ & $\begin{array}{c}\text { I }>\text { median }) \\
1994\end{array}$ & $\begin{array}{l}\text { I(>median) } \\
1994 \text { - Sub- } \\
\text { selection }{ }^{\text {b) }}\end{array}$ \\
\hline $\begin{array}{l}\text { M1: I am willing to work harder than I have } \\
\text { to, to help the company succeed }\end{array}$ & 4 & $\begin{array}{c}3.80 \\
(0.84)\end{array}$ & 4 & $\begin{array}{c}3.70 \\
(0.99)\end{array}$ & $\begin{array}{c}0.15 \\
(0.36)\end{array}$ & $\begin{array}{c}0.19 \\
(0.39)\end{array}$ & $\begin{array}{c}0.63 \\
(0.49)\end{array}$ \\
\hline M2: I feel very little loyalty to the company & 4 & $\begin{array}{c}3.75 \\
(0.91)\end{array}$ & 4 & $\begin{array}{c}3.62 \\
(1.03)\end{array}$ & $\begin{array}{c}0.16 \\
(0.37)\end{array}$ & $\begin{array}{c}0.17 \\
(0.38)\end{array}$ & $\begin{array}{c}0.55 \\
(0.51)\end{array}$ \\
\hline $\begin{array}{l}\text { M3: I would take almost any job to } \\
\text { continue working for the company }\end{array}$ & 2 & $\begin{array}{c}2.38 \\
(1.01) \\
\end{array}$ & 2 & $\begin{array}{c}2.37 \\
(0.95) \\
\end{array}$ & $\begin{array}{c}0.35 \\
(0.48) \\
\end{array}$ & $\begin{array}{c}0.37 \\
(0.48) \\
\end{array}$ & $\begin{array}{c}0.58 \\
(0.50) \\
\end{array}$ \\
\hline M4: I am proud to work for the company & 4 & $\begin{array}{c}3.87 \\
(0.78)\end{array}$ & 4 & $\begin{array}{c}3.78 \\
(0.89)\end{array}$ & $\begin{array}{c}0.19 \\
(0.39)\end{array}$ & $\begin{array}{c}0.19 \\
(0.39)\end{array}$ & $\begin{array}{c}0.65 \\
(0.49)\end{array}$ \\
\hline $\begin{array}{l}\text { M5: Deciding to work for the company was } \\
\text { a real mistake }\end{array}$ & 4 & $\begin{array}{c}4.18 \\
(0.65)\end{array}$ & 4 & $\begin{array}{c}4.07 \\
(0.85)\end{array}$ & $\begin{array}{c}0.31 \\
(0.47)\end{array}$ & $\begin{array}{c}0.31 \\
(0.47)\end{array}$ & $\begin{array}{c}0.64 \\
(0.48)\end{array}$ \\
\hline $\begin{array}{l}\text { M6: I talk up the company to my friends as } \\
\text { a great company to work for }\end{array}$ & 4 & $\begin{array}{c}3.41 \\
(1.03)\end{array}$ & 3 & $\begin{array}{c}3.25 \\
(1.01)\end{array}$ & $\begin{array}{c}0.13 \\
(0.34)\end{array}$ & $\begin{array}{c}0.45 \\
(0.50)\end{array}$ & $\begin{array}{c}0.78 \\
(0.42)\end{array}$ \\
\hline $\begin{array}{l}\text { M7: I really care about the future of the } \\
\text { company }\end{array}$ & 4 & $\begin{array}{c}4.05 \\
(0.76)\end{array}$ & 4 & $\begin{array}{c}4.02 \\
(0.84)\end{array}$ & $\begin{array}{c}0.25 \\
(0.43)\end{array}$ & $\begin{array}{c}0.26 \\
(0.44)\end{array}$ & $\begin{array}{c}0.55 \\
(0.50)\end{array}$ \\
\hline $\begin{array}{l}\text { M8: For me this is the best of all possible } \\
\text { companies for which to work }\end{array}$ & 3 & $\begin{array}{c}2.93 \\
(0.94)\end{array}$ & 3 & $\begin{array}{c}2.97 \\
(1.00)\end{array}$ & $\begin{array}{c}0.28 \\
(0.45)\end{array}$ & $\begin{array}{c}0.31 \\
(0.47)\end{array}$ & $\begin{array}{c}0.66 \\
(0.48)\end{array}$ \\
\hline
\end{tabular}

a) The highest scale corresponds to the highest morale. M1 - M8 are measures at a scale of 1 (strongly agree) to 5 (strongly agree), for which M2 and M5 are reported in reverse coding.

b) As a fraction of the workers who were above median in 1991.

The workers were asked a set of items measuring worker morale in both surveys. They responded to eight questions (M1 - M8) that were developed by Mowday et al. (1982). ${ }^{10}$ See Table 2 for the exact wording of the questions. The eight questions yield internally consistent and highly reliable information on worker morale. First, using all workers in 1991, 25 out of 28 correlations among the responses to these items are positive and statistically different from zero for all pairs of correlations. Second, the reliability of these items is quite high by established psychometric standards (specifically, the standardized Cronbach's alpha is 0.853). Moreover, the response to questions M1-M8 are stable and well-behaved over the two waves of the survey. More specifically, the average values of 1991 and 1994 cannot be distinguished statistically, and the median values are the same for both years. Furthermore, a substantial fraction of workers scored above the median worker morale both in 1994 and in 1991 (see column 7 of Table 2).

\footnotetext{
${ }^{10}$ For questions M2 and M5, we reverse coded the variables such that 5 corresponds to the highest morale.
} 


\section{Identification strategy}

The analysis starts with the empirical analogue of equation (1), in which worker effort is a negative function of the non-pecuniary cost of work. It would give a regression of an indicator of absenteeism (work effort) on commuting time (cost of work). The drawback of such a specification is that the use of information on actual commuting time before and after the plant relocation would lead to inconsistent parameter estimates, because a substantial fraction of workers has moved house between 1991 and 1994 after the plant's relocation (see Table 1). ${ }^{11}$ It is possible to evade the issue of endogeneity by using the shock variable com , so that commuting time in 1994 is considered from the perspective of the worker's residence in 1991 to the plant's new location. ${ }^{12}$ Thus, com is an exogenous shock variable - the plant relocation is neither controlled by the worker nor is it focused on specific groups of workers - which is based on a precise measure of commuting time considered from the worker's residence prior to the plant's relocation. ${ }^{13}$ As a result, com has a zero correlation with the error term of the regression equation, so that the parameter on com registers its causal influence on absenteeism. With the inclusion of individual fixed effects, the major variation comes from the commuting distance before and after the relocation. The empirical specification is

$$
a b s_{i t}=\alpha_{i}+\beta_{1} * \operatorname{com}_{i t}+\delta_{1} D 94_{t}+\delta_{2} \text { DBlue }_{i} D 94_{t}+u_{i t} \quad t=91,94
$$

where the dependent variable $a b s$ is an indicator for absenteeism, which is one if the worker reports absent for one of the working days of a month and zero otherwise. Subscripts $i$ and $t$ refer to worker and year respectively; $\alpha_{i}$ is the unobserved worker-specific effect; $D 94$ is an indicator for the year 1994. Equation (4) also includes an interaction term between an indicator for blue-collar worker (DBlue) and D94. This interaction term allows for any difference in the effect of relocation on absence for the unionized, contract workers versus the salaried workers who are subject to an employment at-will contract. $u$ is an idiosyncratic error term.

\footnotetext{
${ }^{11}$ For this reason, too, we did not apply a dif-in-dif approach.

${ }^{12}$ Thus for the workers who moved house after 1991 as a way of absorbing the shock of the firm relocation, absenteeism would be even larger if they had not changed residence. As a result, our test of com on absenteeism can be considered as a conservative test.

${ }^{13}$ We used round-trip commute time based on road map information estimated from Geographic Information System maps of the Milwaukee area.
} 
Of course, the effect of com on absence may be different for different groups of workers. We test for the alternative hypothesis that the effect of com on absenteeism differs across workers with different levels of worker morale prior to the change of location. We add three interaction terms between a 0-1 indicator for high morale in 1991 and each of the explanatory variables of equation $(4)^{14}$

$$
a b s_{i t}=\alpha_{i}+\gamma^{\prime} X_{i t}+\delta^{\prime} D^{D M h i g h} h_{i, 91} X_{i t}+v_{i t} \quad t=91,94
$$

for which $X_{i t}$ is a vector $\left(\operatorname{com}_{i t}, D 94_{t}, D B l u e_{i} D 94_{t}\right)$.DMhigh is a 0-1 indicator (based on one of the variables of morale M1-M8), which is one if the worker has a value of morale above the median in 1991 (the median values are reported in Table 2). $\gamma$ and $\delta$ are vectors of parameters. The implication of the inclusion of DMhigh is that the level of morale - ex ante, prior to the plant's relocation - absorbs the positive effect of commuting time (equation (3)). If so, the parameter $\delta_{1}$ on the interaction term $D M h i g h_{i, 91} \operatorname{com}_{i t}$ has a negative sign. Equation (5) will be estimated separately for each dimension of work morale (M1-M8).

Equation (5) is based on the assumption that $D M h i g h_{i, 91}$ is unrelated to $\operatorname{com}_{94}$. In other words, there is no relationship between morale in 1991 and the size of the shock in distance (1991 residence to the new location of factory). This assumption can be tested by considering the parameter $\kappa_{1}$ of the regression of morale:

$$
\begin{aligned}
& M_{i t}=\lambda_{i}+\kappa_{1} * \operatorname{com}_{i t}+\kappa_{2} * \text { DOutsidehigh }{ }_{i t}+\tau_{1} D 94_{t}+\tau_{2} \text { DBlue }_{i} D 94_{t}+w_{i t} \\
& t=91,94
\end{aligned}
$$

where the dependent variable $M$ is one of the dimensions of morale (M1-M8). It implies that a shock of commuting time does not affect morale $\left(\kappa_{1}=0\right)$. In addition the indicator variable DOutsidehigh measures the quality of the outside option, which is one if the worker reported that he can easily find another job (above the median value). A negative $\kappa_{2}$ implies that workers with a better outside option have a lower morale.

\footnotetext{
${ }^{14}$ Equations (5) and (6) are formulated at the level of one of the dimensions of worker morale (M1M8). For clearness of exposition, the parameters and the error terms of both equations do not include superscripts that refer to M1-M8.
} 
Table 3 - Equation (4) (dependent: 0-1 indicator for monthly absence) ${ }^{\text {a), b) }}$

\begin{tabular}{|c|c|c|}
\hline & (1) & (2) \\
\hline com & $\begin{array}{c}0.115 \\
(0.128) \\
\end{array}$ & $\begin{array}{c}0.208 \\
(0.127) \\
\end{array}$ \\
\hline D94 & $\begin{array}{c}-0.248 * * * \\
(0.046)\end{array}$ & $\begin{array}{c}-0.157 * * * \\
(0.051)\end{array}$ \\
\hline DBlue *D94 & - & $\begin{array}{c}-0.211 * * * \\
(0.079)\end{array}$ \\
\hline$\sigma_{\alpha}$ & 0.348 & 0.381 \\
\hline$\sigma_{u}$ & 0.383 & 0.377 \\
\hline Number of observations & 356 & 356 \\
\hline Number of workers & 178 & 178 \\
\hline
\end{tabular}

a) Fixed-effects LPM. Standard errors clustered on worker reported in parentheses.

b) com : road map commuting time from 1991 residence to new or old location. D94: indicator for 1994. DBlue*D94: interaction term between indicators for blue-collar worker and 1994.

*** Statistically significantly different from zero at the .01 level.

\section{Estimates}

We estimated equations (4)-(6) as a fixed-effects Linear Probability Model with standard errors that are clustered on worker. The benchmark estimates are based on a sample of 178 workers who were at the firm in both 1991 and 1994. As a measure of commuting time we use commuting time based on road-map distances. In Table 3, we present estimates of equation (4). The effect of commuting time on absenteeism is statistically insignificant at the 10-percent level. Furthermore, the estimated parameters (column 2) imply a decrease of absence of 16 percentage points from 1991 to 1994. For blue-collar workers there was an additional decrease of 21 percentage points. These outcomes are in line with the statistics of Table 1. 
Table 4 - Estimates of equation (4) for different selections of worker morale (dependent: 0-1 indicator for monthly absence) ${ }^{\text {a) }}$

\begin{tabular}{|c|c|c|c|c|c|c|c|c|}
\hline \multirow{3}{*}{$\begin{array}{l}\text { Selection based on } \\
\text { dimension of worker } \\
\text { morale in } 1991 \text { b) }\end{array}$} & \multicolumn{4}{|c|}{$\begin{array}{c}\text { Selection of worker morale: median and } \\
\text { below in } 1991 \text { (low morale) }\end{array}$} & \multicolumn{4}{|c|}{$\begin{array}{c}\text { Selection of worker morale: above median in } \\
1991 \text { (high morale) }\end{array}$} \\
\hline & \multicolumn{3}{|c|}{ Independent variables $^{c}$ ) } & \multirow{2}{*}{$N$} & \multicolumn{3}{|c|}{ Independent variables $^{c}$} & \multirow{2}{*}{$N$} \\
\hline & com & $D 94$ & DBlue*D94 & & com & $D 94$ & DBlue $* D 94$ & \\
\hline M1 & $\begin{array}{l}0.281^{*} \\
(0.144)\end{array}$ & $\begin{array}{c}-0.140 * * \\
(0.059)\end{array}$ & $\begin{array}{c}-0.255^{* * *} \\
(0.089)\end{array}$ & 302 & $\begin{array}{c}-0.112 \\
(0.213)\end{array}$ & $\begin{array}{l}-0.164 \\
(0.102)\end{array}$ & $\begin{array}{l}-0.138 \\
(0.216)\end{array}$ & 54 \\
\hline M2 & $\begin{array}{l}0.286^{* *} \\
(0.143)\end{array}$ & $\begin{array}{c}-0.162 * * * \\
(0.063)\end{array}$ & $\begin{array}{c}-0.249 * * * \\
(0.089) \\
\end{array}$ & 298 & $\begin{array}{l}-0.180 \\
(0.180)\end{array}$ & $\begin{array}{l}-0.106 \\
(0.076)\end{array}$ & $\begin{array}{c}0.052 \\
(0.144)\end{array}$ & 58 \\
\hline M3 & $\begin{array}{l}0.333 * * \\
(0.151)\end{array}$ & $\begin{array}{c}-0.155^{* *} \\
(0.061) \\
\end{array}$ & $\begin{array}{c}-0.242 * * \\
(0.099) \\
\end{array}$ & 232 & $\begin{array}{l}-0.052 \\
(0.217) \\
\end{array}$ & $\begin{array}{c}-0.171^{*} \\
(0.097) \\
\end{array}$ & $\begin{array}{l}-0.136 \\
(0.126)\end{array}$ & 124 \\
\hline M4 & $\begin{array}{c}0.317 * * \\
(0.141)\end{array}$ & $\begin{array}{l}-0.121^{*} \\
(0.062)\end{array}$ & $\begin{array}{c}-0.281 * * * \\
(0.086)\end{array}$ & 288 & $\begin{array}{l}-0.243 \\
(0.219)\end{array}$ & $\begin{array}{c}-0.171 * * \\
(0.080)\end{array}$ & $\begin{array}{l}-0.192 \\
(0.213)\end{array}$ & 68 \\
\hline M5 & $\begin{array}{l}0.284^{*} \\
(0.162)\end{array}$ & $\begin{array}{c}-0.151 * * \\
(0.072) \\
\end{array}$ & $\begin{array}{c}-0.233^{* *} \\
(0.103) \\
\end{array}$ & 244 & $\begin{array}{c}0.045 \\
(0.194) \\
\end{array}$ & $\begin{array}{l}-0.136^{*} \\
(0.076) \\
\end{array}$ & $\begin{array}{l}-0.254 \\
(0.164) \\
\end{array}$ & 112 \\
\hline M6 & $\begin{array}{l}0.291 * * \\
(0.142) \\
\end{array}$ & $\begin{array}{c}-0.182 * * * \\
(0.061)\end{array}$ & $\begin{array}{c}-0.232 * * * \\
(0.088)\end{array}$ & 310 & $\begin{array}{c}-0.253 \\
(0.184) \\
\end{array}$ & $\begin{array}{c}-0.004 \\
(0.034) \\
\end{array}$ & $\begin{array}{l}-0.030 \\
(0.139) \\
\end{array}$ & 46 \\
\hline M7 & $\begin{array}{c}0.219 \\
(0.154) \\
\end{array}$ & $\begin{array}{c}-0.176 * * \\
(0.069)\end{array}$ & $\begin{array}{c}-0.220 * * \\
(0.100)\end{array}$ & 268 & $\begin{array}{c}0.171 \\
(0.220) \\
\end{array}$ & $\begin{array}{c}-0.117 * \\
(0.068) \\
\end{array}$ & $\begin{array}{l}-0.123 \\
(0.157)\end{array}$ & 88 \\
\hline M8 & $\begin{array}{l}0.331 * * \\
(0.147)\end{array}$ & $\begin{array}{c}-0.161 * * \\
(0.065) \\
\end{array}$ & $\begin{array}{c}-0.278 * * * \\
(0.092) \\
\end{array}$ & 256 & $\begin{array}{l}-0.052 \\
(0.226) \\
\end{array}$ & $\begin{array}{c}-0.157 * * \\
(0.079) \\
\end{array}$ & $\begin{array}{l}-0.056 \\
(0.147)\end{array}$ & 100 \\
\hline Average of M1 - M8 & $\begin{array}{l}0.337^{*} \\
(0.173)\end{array}$ & $\begin{array}{l}-0.123 \\
(0.085)\end{array}$ & $\begin{array}{c}-0.318 * * \\
(0.118)\end{array}$ & 206 & $\begin{array}{c}0.044 \\
(0.167)\end{array}$ & $\begin{array}{c}-0.165 * * \\
(0.067)\end{array}$ & $\begin{array}{l}-0.085 \\
(0.114)\end{array}$ & 150 \\
\hline
\end{tabular}

a) Fixed-effects LPM. Standard errors clustered on worker reported in parentheses. Each row reports a separate regression. $N$ : number of observations.

b) See Table 2 for the definitions and the 1991-medians of questions M1-M8.

c) See Table 3 for the definitions of the independent variables. Estimated parameter on intercept is not reported.

*Statistically significantly different from zero at the .10 level; **at the .05 level; ***at the .01 level.

For each dimension of worker morale (M1-M8), we take sub-selections of workers who had a score either above or equal and below the median value of the specific question of morale in 1991. See the first column of Table 2 for the median of these variables. Table 4 reports the estimated parameters on com, D94, and DBlueD94 for both sub-selections separately (so that the table is based on 16 estimated regression equations). The major finding is that an increase in the estimated commuting time by one hour increased worker absence by $0.2-0.3$ day per month among workers who previously self-reported lower morale, but such an effect is muted among workers who self-reported high morale. The impression overall is that for low-morale workers, there is a positive effect of commuting time on absence for most of the questions. In contrast, for the group of high-morale workers, there is no effect of commuting time on 
absenteeism. The fact that M1-M8 hang together in a valid scale suggests that it would be fine to combine them - the simplest way is a simple average across the eight variables. There is a negative effect of commuting time on absence for the low-morale workers, using the average of M1-M8.

Table 5 - Estimates of equation (5) for various dimensions of worker morale (dependent: 0-1 indicator for monthly absence) $)^{\text {a) }}$

\begin{tabular}{|l|c|c|}
\hline \multirow{2}{*}{$\begin{array}{l}\text { Dimension of worker morale } \\
\text { in 1991 b) }\end{array}$} & \multicolumn{2}{|c|}{ Independent variables } \\
\cline { 2 - 3 } & DMhigh*com & com \\
\hline \multirow{2}{*}{ M1 } & -0.392 & $0.281^{*}$ \\
& $(0.251)$ & $(0.144)$ \\
\hline \multirow{2}{*}{ M2 } & $-0.466^{* *}$ & $\begin{array}{c}0.286^{* *} \\
(0.144)\end{array}$ \\
\hline \multirow{2}{*}{ M3 } & $(0.225)$ & $0.333^{* *}$ \\
& -0.384 & $(0.151)$ \\
\hline \multirow{2}{*}{ M4 } & $(0.262)$ & $0.317^{* *}$ \\
& $-0.559^{* *}$ & $(0.141)$ \\
\hline \multirow{2}{*}{ M5 } & $(0.256)$ & $0.284^{*}$ \\
& -0.239 & $(0.162)$ \\
\hline \multirow{2}{*}{ M6 } & $(0.251)$ & $0.291^{* *}$ \\
& $-0.543^{* *}$ & $(0.143)$ \\
\hline \multirow{2}{*}{ M7 } & $(0.227)$ & 0.219 \\
& -0.048 & $(0.154)$ \\
\hline \multirow{2}{*}{ M8 } & $(0.265)$ & $0.331^{* *}$ \\
& -0.383 & $(0.148)$ \\
\hline \multirow{2}{*}{ Average of M1 - M8 } & $(0.268)$ & $0.337^{*}$ \\
& -0.293 & $(0.173)$ \\
\hline
\end{tabular}

a) Fixed effects LPM. Standard errors clustered on worker reported in parentheses. Each row contains a separate regression. 356 observations.

b) Each regression estimate includes six explanatory variables. Not reported are estimated parameters on intercept, D94, DBlueD94, interaction terms between 0-1 indicator for high worker morale (DMHigh) and D94, and the interaction term between DMhigh and DBlueD94.

c) See Table 2 for the definitions and the 1991-medians of questions M1-M8.

*Statistically significantly different from zero at the .10 level; **at the .05 level; ***at the .01 level.

Table 5 reports the estimated parameters of equation (5) for each of the questions of worker morale M1-M8 in 1991. By including the interaction terms with morale, the parameter on commuting time becomes positive and statistically significant from zero for all questions, except for M7. For three out of eight questions of morale (M2, M4, and M6), the interaction term is negative and statistically significant. For the average of M1-M8, the estimate of the parameters on com is positive and statistically significant, whereas DMhigh*com is 
statistically insignificant. These estimates too suggest that the effect of commuting time on absenteeism is smaller for workers with high morale prior to the relocation of the firm.

\section{Robustness checks}

We discuss two robustness checks on the benchmark estimates. A first issue concerns the possible endogeneity and interpretation of the effect of worker morale in equation (5). One could argue that the estimates are affected by the timing of the first interview with the workers. It was held at the moment the pending plant's relocation was known to the workers, so that it may have influenced their worker morale. It means that the negative effect of commute on absence would be correlated with the morale. If this argument were correct, the effect of commuting time com on worker morale (equation (6)) would be negative and statistically significant. ${ }^{15}$ Another argument against the outcomes of the benchmark estimates is that worker morale reflects the lack of possibilities of the worker in the outside labor market. We check for both possibilities by estimating equation (6). If this argument is right, there would be two testable implications. First, the effect of the outside option on morale (equation (6)) would be statistically significant. And second, the outcomes of equation (5) would also hold true for the interaction with respect to the outside option.

\footnotetext{
${ }^{15}$ There are two additional findings that suggest that a substantial change of morale is unlikely to be associated with the announcement of the firm move. We found no evidence of workers' changing their behavior in the pre1991 period. First, annual worker turnover did not change between the pre-move period (1989-1991) and the post-move period (1991-1994). Second, for workers who stayed with the firm, household moves were random between 1989 and 1991, whereas household moves were in the 1991 -1994 period were in the direction of the new plant (see Fernandez 2008).
} 
Table 6 - Estimates of equation (6) (dependent: M1-M8)

\begin{tabular}{|c|c|c|c|c|c|c|c|c|}
\hline & M1 & M2 & M3 & M4 & M5 & M6 & M7 & M8 \\
\hline com & $\begin{array}{l}-0.111 \\
(0.237)\end{array}$ & $\begin{array}{l}-0.219 \\
(0.228)\end{array}$ & $\begin{array}{c}-0.024 \\
(0.262)\end{array}$ & $\begin{array}{l}-0.334^{*} \\
(0.185)\end{array}$ & $\begin{array}{c}-0.299 \\
(0.207)\end{array}$ & $\begin{array}{c}0.054 \\
(0.216)\end{array}$ & $\begin{array}{c}-0.256 \\
(0.187)\end{array}$ & $\begin{array}{c}-0.144 \\
(0.223)\end{array}$ \\
\hline DOutsidehigh & $\begin{array}{c}-0.044 * * \\
(0.021)\end{array}$ & $\begin{array}{l}-0.024 \\
(0.031)\end{array}$ & $\begin{array}{c}-0.048 * \\
(0.028)\end{array}$ & $\begin{array}{l}-0.023 \\
(0.021)\end{array}$ & $\begin{array}{c}-0.042 * * \\
(0.021)\end{array}$ & $\begin{array}{c}-0.047 * \\
(0.025)\end{array}$ & $\begin{array}{l}-0.029 * \\
(0.017)\end{array}$ & $\begin{array}{c}-0.078 * * * \\
(0.023)\end{array}$ \\
\hline D94 & $\begin{array}{l}-0.069 \\
(0.093) \\
\end{array}$ & $\begin{array}{l}-0.077 \\
(0.097) \\
\end{array}$ & $\begin{array}{l}-0.010 \\
(0.113) \\
\end{array}$ & $\begin{array}{c}0.006 \\
(0.075) \\
\end{array}$ & $\begin{array}{l}-0.032 \\
(0.082) \\
\end{array}$ & $\begin{array}{c}-0.171 * * \\
(0.076)\end{array}$ & $\begin{array}{c}0.039 \\
(0.080) \\
\end{array}$ & $\begin{array}{c}0.074 \\
(0.095) \\
\end{array}$ \\
\hline$\sigma_{\lambda}$ & 0.807 & 0.864 & 0.799 & 0.784 & 0.687 & 0.896 & 0.710 & 0.839 \\
\hline$\sigma_{w}$ & 0.661 & 0.714 & 0.776 & 0.545 & 0.569 & 0.684 & 0.595 & 0.696 \\
\hline $\begin{array}{l}\text { Number of } \\
\text { observations }\end{array}$ & 353 & 351 & 353 & 353 & 351 & 351 & 353 & 353 \\
\hline
\end{tabular}

a) Fixed-effects LPM. Standard errors clustered on worker reported in parentheses. Each column represent a separate regression equation.

b) See Table 2 for the definitions of M1-M8. See Table 3 for the definitions of com and D94. DOutsidehigh is a $0-1$ indicator which is one if difficulty of finding another job is above the median in year $t(1=$ easy).

*Statistically significantly different from zero at the .10 level; **at the .05 level; ***at the .01 level.

We investigate the validity of this issue by running regressions of different dimensions of morale (equation (6)) for the stayers (see Table 6). There are three results. First, the shock variable has no influence on worker morale for all measures (except for M4, which is significant at the 10-percent level). Furthermore, there was no substantial change of worker morale between the two waves of the study. Both results suggests that endogeneity of worker morale in equation (5) is not an important issue. In addition, the estimates imply that worker morale is negatively correlated with the outside option, and therefore, it would be incorrect to interpret the parameter estimates as a causal effect. We further investigated this interpretation of worker morale by re-estimating equation (5) for workers above (and below) the median value of the outside option prior to the plant relocation. The estimates do not imply any difference in the effect of effect of commuting time on absence. It suggests that although morale is related to the outside option, it cannot explain the difference in effect of the shock variable on absence. 
Table 7 - Estimates of leave equation for various dimensions of worker morale (dependent: $0-1$ indicator for leaver) ${ }^{\text {a) }}$

\begin{tabular}{|l|c|c|}
\hline \multirow{2}{*}{$\begin{array}{l}\text { Dimension of worker } \\
\text { morale in 1991 }\end{array}$} & \multicolumn{2}{|c|}{ Independent variables } \\
& b) \\
\hline \multirow{2}{*}{ No DMhigh included } & DMhigh*com & com \\
\hline \multirow{2}{*}{ M1 } & - & -0.030 \\
& 0.010 & $(0.064)$ \\
\hline \multirow{2}{*}{ M2 } & $(0.140)$ & -0.039 \\
& $-0.241^{* *}$ & $(0.073)$ \\
\hline \multirow{2}{*}{ M3 } & $(0.118)$ & 0.023 \\
& $-0.327^{*}$ & $(0.074)$ \\
\hline \multirow{2}{*}{ M4 } & $(0.194)$ & -0.006 \\
& $-0.212^{*}$ & $(0.067)$ \\
\hline \multirow{2}{*}{ M5 } & $(0.121)$ & 0.015 \\
& -0.042 & $(0.074)$ \\
\hline \multirow{2}{*}{ M6 } & $(0.118)$ & -0.012 \\
& 0.095 & $-0.091)$ \\
\hline \multirow{2}{*}{ M7 } & $(0.320)$ & $(0.034$ \\
& -0.137 & 0.011 \\
\multirow{2}{*}{ M8 } & $(0.145)$ & $(0.075)$ \\
\hline \multirow{2}{*}{ Average of M1 - M8 } & $-0.195^{*}$ & 0.017 \\
& $(0.111)$ & $(0.076)$ \\
\hline
\end{tabular}

a) Robust standard errors in parentheses. Dependent: 0-1 indicator which is one if the worker left the firm between 1991 and 1994. Each row reports a separate regression. 268 observations.

b) See Table 3 for the definition of com. DMHigh is 0-1 indicator for high worker morale. The table does not report the estimated parameters on the intercept, indicator for blue-collar worker, and Dmhigh.

*Statistically significantly different from zero at the .10 level; **at the .05 level.

A second issue with the benchmark estimates is that the effect of commute on absenteeism is for the stayers only, so that the response is considered at the intensive margin of workers effort. We broaden this effect to the leavers (effort at the extensive margin) by regressing an indicator of leaving the firm on the interaction of morale and the commuting shock. Although the specification does not include fixed effects, the commuting time variable com is not correlated to the error term of the regression equation. Table 7 reports the regression results of the separation equation for the various dimensions of morale (M1-M8). The estimated parameter on the interaction term of morale and the shock variable is statistically significant for four out of eight regressions (M2, M3, M4, M8). Furthermore the average of these four morale indicators gives a negative and statistically significant interaction term. It suggests that workers with high morale are less inclined to leave the firm if 
they experience an unfavorable shock of commuting time. Hence, the benchmark estimates can be interpreted as a lower bound of the total effect at the intensive and extensive margin.

\section{Conclusion}

Using a natural experiment design, we provided estimates of the causal effect of an exogenous shock of commuting distance - a measure of non-pecuniary cost of work - on worker effort. Our estimates render new insights of its interaction with worker morale, which opens avenues for further research. Our main conclusions are threefold.

First, the estimates indicate the negative effect is stronger for workers with low morale prior to the shock, whereas it is reduced to zero for high-morale workers. This empirical outcome is consistent with the theoretical framework that was formulated by Akerlof and Yellen (1990). It bolsters the case made by Fehr and Falk (1999) and Fehr and Gächter (2002) about the importance of morale for short-run relationships in experimental settings Furthermore, it generalizes previous empirical studies in which worker morale was represented by worker reciprocity during adverse circumstances (Lee and Rupp, 2007). The empirical outcome implies that worker morale cushions the effect of adverse shocks to the worker's non-pecuniary cost of work on their work performance. A question for further research is whether this outcome can be generalized to a system of financial incentives. Although the effect of negative financial incentives on work performance in the workplace has been widely analyzed, there is no empirical investigation about its interaction with worker morale.

Second, an important issue that results from our estimates is how firms can strengthen worker morale. One could argue that a higher wage - and thus a weaker outside option would reinforce worker morale, because it would exacerbate the negative financial consequences of a possible dismissal. Indeed, our fixed-effects estimates indicate a negative relation between worker morale and the worker's value of the outside option. However, our estimates also indicated that the outcome of the shock of commuting distance on work effort is irrespective of the value of the outside option, so that there is no indication that our major result is due to the influence of the outside option. Our result that worker morale did not change across time for the stayers raises the question of how firms can influence morale, and how costly it is to increase worker morale. Are there any specific stages of the work career in which it is more effective to influence worker morale, for instance during the probationary period (Akerlof and Kranton, 2005)? 
Third, in our analysis, work performance is the sum of effort at the extensive margin (the decision of leaving the firm) and effort the intensive margin (the decision to report absent for the stayers). So far, most of the empirical analysis on work performance consider both types of effort from an isolated perspective (Manning, 2003; Treble and Barmby, 2011). Our estimates imply that worker morale cushions the effect of commute for both types of effort. It gives indirect evidence that the firm gets high-morale stayers to weather unforeseen shocks. Because high-morale stayers have a lower incidence of absence, it results in a separating equilibrium. This outcome indicates that worker morale may provide an interaction between effort at the intensive margin (absence) and the extensive margin (resignations). 


\section{References}

Akerlof, G.A. (1982), "Labor Contracts as Partial Gift Exchange," Quarterly Journal of Economics, vol. 97 (4), pp. 543-569.

Akerlof, G.A. and J.L. Yellen (1990), "The Fair Wage-Effort Hypothesis and Unemployment," Quarterly Journal of Economics, vol. 105 (2), pp. 255-283.

Akerlof, G.A and R.E. Kranton (2005), "Identity and the Economics of Organizations," Journal of Economic Perspectives, vol. 19 (1), pp. 9-32.

Allen, S.G. (1981), “An Empirical Model of Work Attendance," Review of Economics and Statistics, vol. 63 (1), pp. 77-87.

Arai, M. and P.S. Thoursie (2005), "Incentives and Selection in Cyclical Absenteeism", Labour Economics, 12 (2), pp. 269-280.

Barmby, T., Orme, C., and J. Treble (1991), "Worker Absenteeism: An Analysis Using Microdata", Economic Journal, vol. 101 (405), pp. 214-229.

Bewley, T.F. (1998), “Why not Cut Pay?,” European Economic Review, vol. 42, pp. 459-490.

Bewley, T.F. (1999), Why Wages Don't Fall During a Recession," Harvard University Press.

Bolton, P. (1990), "Renegotiation and the Dynamics of Contract Design," European Economic Review, vol. 34, pp. 303-310.

Campbell, C.M. and K.S. Kamlani (1997), "The Reasons For Wage Rigidity: Evidence From A Survey Of Firms,” Quarterly Journal of Economics, vol. 112 (3), pp. 759-789.

Cohn, A., Fehr, E., Herrmann, B, and F. Schneider (2011), "Social Comparison in the Workplace: Evidence from a Field Experiment,” IZA DP No. 5550.

Fehr, E. and A. Falk (1999), "Wage Rigidity in a Competitive Incomplete Contract Market," Journal of Political Economy, vol. 107 (1), pp. 106-134.

Fehr, E. and S. Gächter (2000), "Fairness and Retaliation: The Economics of Reciprocity," Journal of Economic Perspectives, vol. 14 (3), pp. 159-181.

Fernandez, R.M. (1994), "Race, Space, and Job Accessibility: Evidence from a Plant Relocation," Economic Geography, vol. 70 (4), pp. 390-416.

Fernandez, R.M. (2001), "Skill-Biased Technological Change and Wage Inequality: Evidence from a Plant Retooling," American Journal of Sociology, vol. 107 (2), pp. 273-320.

Fernandez, R.M. (2008), "Race, Spatial Mismatch, and Job Accessibility: Evidence from a Plant Relocation," Social Science Research, vol. 37 (3), pp. 953-975.

Fernandez, R.M. (2004), "Space in the Study of Labor Markets," Annual Review of Sociology 30: $545-569$. 
Hirschmann, A.O. (1970), Exit, Voice, and Loyalty: Responses to Decline in Firms, Organizations, and States. Harvard University Press.

Hassink, W.H.J. and P. Koning (2009), "Do Financial Bonuses Reduce Employee Absenteeism? Evidence from a Lottery," Industrial and Labor Relations Review, (2009), vol. 62 (3), pp. 327-342.

Ichino, A. and E. Moretti (2009). Biological gender differences, absenteeism and the earning gap. American Economic Journal: Applied Economics, Vol. 1 (1), 183-218.

Ichino, A. and R. Riphahn (2005), "The Effect of Employment Protection on Worker Effort: A Comparison of Absenteeism During and After Probation," Journal of the European Economic Association, vol. 3 (1), pp. 120-143.

Johansson, P., and M. Palme (1996), "Do economic incentives affect work absence? empirical evidence using Swedish micro data," Journal of Public Economics, vol. 59 (2), pp. 195-218.

Kandel, E. and E.P. Lazear (1992), "Peer Pressure and Partnerships," Journal of Political Economy, vol. 100 (4), pp. 801-817.

Kube, S., Maréchal, M.A. and C. Puppe (2012), "The Currency of Reciprocity - GiftExchange in the Workplace," American Economic Review, vol. 102, pp. 1644-1662.

Lee, D. and N.G. Rupp (2007), "Retracting a Gift: How Does Employee Effort Respond to Wage Reductions?," Journal of Labor Economics, vol. 25 (4), pp. 725-761.

Manning, A. (2003), Monopsony in motion: Imperfect competition in labor markets. Princeton, NJ: Princeton University Press.

Mowday, R.T., L.W. Porter and R.M. Steers. (1982), Employee-Organization Linkages: The Psychology of Commitment, Absenteeism, and Turnover. San Diego, CA.: Academic Press.

National Partnership for Women \& Families (2013), Tracking document. State and Local Action on Paid Sick Days.

O'Reilly, C.A. and J. Pfeffer (2000), Hidden Value: How Great Companies Achieve Extraordinary Results with Ordinary People, Harvard Business School Press.

Pfeffer, J. (1994), Competitive Advantage Through People: Unleashing the Power of the Work Force, Harvard Business School Press.

1998. The Human Equation, Harvard Business School Press.

Podsakoff, Ph.M, MacKenzie, Sc.B., Beth Paine, J, and Bachrach, D.G. (2000), "Organizational Citizenship Behaviors: A Critical Review of the Theoretical and Empirical Literature and Suggestions for Future Research" Journal of Management, vol. 26 (3), pp. 513-563. 
Podsakoff, N.P., Whiting, S.W., Podsakoff, Ph.M., and B.D. Blume (2009), "Individual- and Organizational-Level Consequences of Organizational Citizenship Behaviors: A MetaAnalysis," Journal of Applied Psychology, vol. 94 (1), pp. 122-141.

Røed, K. and E. Fevang (2007), "Organizational Change, Absenteeism, and Welfare Dependence," Journal of Human Resources, Vol. 42 (1), 156-193.

Treble, J. and T.A. Barmby (2011), Worker Absenteeism and Sick Pay. Cambridge University Press.

Vistnes, J.P. (1997), “Gender Differences in Days Lost from Work Due to Illness," Industrial and Labor Relations Review, vol. 50 (2), pp. 304-323.

Zax, J.S. (1989), “Quits and race,” Journal of Human Resources, vol. 24, pp. 469-493.

Zax, J.S. (1990), “Race and commutes,” Journal of Urban Economics vol. 28, pp. 336-348.

Zax, J.S. and J.F. Kain (1991), "Commutes, quits and moves," Journal of Urban Economics, vol. 29, pp. 153-165.

Zax, J.S. and J.F. Kain (1996), "Moving to the suburbs: do relocating companies leave their workers behind?," Journal of Labor Economics, vol. 14, pp. 472-504.

Ziebarth, N.R. and M. Karlsson (2014), "The effects of expanding the generosity of the statutory sickness insurance system," Journal of Applied Econometrics, Vol. 29 (3): 208-230. 